вариант заболевания, названный проксимальной миотонической миопатией (П ММ). У большинства семей с ПММ был обнаружен дефект в недавно открытом локусе DM2 хромосомы 3q21. Исследование посвящено клиническому анализу этого заболевания у 70 пациентов из 14 немецких семей. В отличие от болезни Штейнерта, ПММ у большинства пациентов имеет более доброкачественное течение. В клинической картине, как правило, не обнаруживается умственная отсталость; мышечная слабость наблюдается лишь в проксимальной мускулатуре нижних конечностей; миотонический синдром выражен слабо или отсутствует, нмеет место бо- левой синдром. Тем не менее при ПММ у части пациентов существует возможность серьезных сердечных осложнений и вероятность прогрессирования мышечной слабости. Авторами наблюдаются некоторые пациенты, имеющие фенотипические варианты ПММ, однако у них не обнаружены нарушения в хромосоме 3q21. Это дает основания полагать, что группа описанных типов миотони. ческих дистрофий может пополниться в будушем новыми вариантами заболевания.

Германия,

Department of Neurology, University of Wurzburg

\title{
D. Biondi
}

\section{ЦЕРВИКОГЕННАЯ ГОЛОВНАЯ БОЛЬ: МЕХАНИЗМ, КЛИНИКА И СТРАТЕГИЯ ЛЕЧЕНИЯ}

\author{
(CERVICOGENIC HEADACHE: MECHANISMS, EVALUATION \\ AND TREATMENT STRATEGIES)
}

(J. Am. Osteopath. Assoc.- 2000. Sep.-100(9 Suppl.).-S7-14: Англ.)

\section{II} ервикогенная головная боль - хронический гемикраниальный болевой синдром, развивающийся вследствие патологии шейного отдела позвоночника или мягких тканей шеи. Известно, что тригемино-цервикальное ядро - это регион в верхней части спинного мозга, где чувствительные нервные волокна нисходящего тракта тригеминального нерва конвергируют с чувствительными волокнами верхних шейных корешков. Посредством данной конвергенции ноцицептивных путей отраженные болевые сигналы от шеи достигают тригеминальных чувствительных рецептивных полей лица и головы, активируя тригемино-васкулярные нервные окончания. В свою очередь, существуют связи сенсомоторных волокон добавочного нерва и верхних спинальных корешков, которые также конвергируют с нисходящим трактом тригеминального нерва, что является бази- сом для передачи болевых импульсов с грудинно-ключично-сосцевидной и трапециевидной мышц в область лица и головы. Дифференциальная диагностика цервикогенной головной боли проводится с мигренью, головной болью напряжения и пароксизмальной гемикранией. Статья посвящена клинической характеристике цервикогенной гояовной боли, ее диагностическим критериям, патофизиологии и методам диагностической экспертизы. Предлагается программа лечения цервикогенной головной боли, включающая медикаментозную терапию, анестезиологические вмешательства, остеопатические манипуляционные процедуры и другие нефармакологические методы.

CIIIA,

Head Pain Division, Michigan Head-Pain \& Neurological Institute 